\title{
Investigation on Maximization of Seed Quality and through Integrated Approach in Prosomillet (Panicum miliaceum L.)
}

\author{
U. Tejaswini ${ }^{1}$, S.M. Prashant ${ }^{1}$, N.M. Shakuntala, \\ Sangeetha I. Macha ${ }^{1}$ and D. Krishnamurthy ${ }^{2}$
}

${ }^{I}$ Department of Seed Science and Technology, ${ }^{2}$ Department of Agronomy, College of Agriculture, Raichur, University of Agricultural Sciences, Raichur- 584 104, India

*Corresponding author

\section{A B S T R A C T}

\begin{tabular}{|c|}
\hline Keywords \\
\hline $\begin{array}{l}\text { Priming, Quality, } \\
\text { Prosomillet, } \\
\mathrm{KH}_{2} \mathrm{PO}_{4}, \mathrm{RDF}\end{array}$ \\
\hline Article Info \\
\hline $\begin{array}{l}\text { Accepted: } \\
04 \text { August } 2019 \\
\text { Available Online: } \\
\text { 10 September } 2019\end{array}$ \\
\hline
\end{tabular}

A laboratory experiment was conducted at seed science and technology, college of agriculture, Raichur during December, 2018. Aim is to study the effect of seed quality through integrated approach in prosomillet of resultant seeds. The experiment consisted of 4 priming treatment combinations viz., Control, hydropriming for $8 \mathrm{~h}$, biopriming with Pseudomonas fluorescens $(20 \%)$ and $\mathrm{KH}_{2} \mathrm{PO}_{4}(2 \%)$ with three levels of fertility (100\%, $125 \%$ and $150 \%$ RDF). The seeds produced from the field experiment are evaluated in the laboratory for quality assessment. The seed quality parameters differed significantly between the treatments. Seed priming with Pseudomonas fluorescens $(20 \%)$ along with $150 \%$ RDF recorded higher germination percentage $(89.2 \%)$, shoot length $(13.02 \mathrm{~cm})$, root length $(11.63 \mathrm{~cm})$, seedling length $(24.65 \mathrm{~cm})$, seedling dry weight $(430 \mathrm{mg})$, seedling vigour index I and II (2198 and 38356) and electrical conductivity (0.015) were influenced significantly by Pseudomonas fluroscens (20\%) along with $150 \%$ RDF among all the treatments.

\section{Introduction}

Proso millet (Panicum miliaceum L.) is commonly known as broomcorn millet, common millet, hog millet, Russian millet and so on, in different parts of the world. Proso millet is currently grown in Asia, Australia, North America, Europe, and Africa (Gavit et al., 2017), and used for feeding birds and as livestock feed in the developed countries and for food in some parts of Asia. Proso millet is likely to have originated in Manchuria (Patil et al., 2015), and it is widely grown in temperate climates across the world. It is an important crop in Northwest China and is grown in Kazakhastan, the Central and Southern states of India and Eastern Europe, USA, and Australia. It is generally cultivated in the cooler regions of Asia, Eastern Africa, southern Europe, and the United States. Prosomillet has adapted well to temperate plains and high altitudes compared to other millets.

Seed is a basic input in agriculture in which 25 $\%$ yield increase can be achieved by quality seeds. Quality seed is the key for successful agriculture, which demands each and every 
seed should be readily germinable and produce a vigorous seedling ensuring higher yield. To provide higher quality seeds, many researchers have developed new technologies called "Seed Enhancement Techniques".

Priming technique is the need of present time to get the enhanced germination and establishment in order to utilize the soil moisture and solar radiation to a maximum extent. In this way plants would be able to complete their growth before the stresses arrive (Subedi and Ma, 2005). Osmopriming is commercially used technique for improving seed germination and vigour. It involves controlled imbibition of seeds to start the initial events of germination followed by seed drying up to its original weight. Osmopriming has many advantages including rapid and uniform emergence, improved seedling growth and better stand establishment under any environmental and soil conditions (Chiu et al., 2002).

Research on priming has proved that crop seeds primed with water germinated early, root and shoot development started rapidly, grew more vigorously and seedling length was also significantly greater than nonprimed seeds. It could also improve the performance of crop by alleviating the effect of salts under saline soil conditions (Mohammadi et al., 2008). Soaking seed in water overnight before sowing can increase the rate of germination and emergence even in soil conditions where moisture content is very low (Clark et al., 2001).

Biopriming with Pseudomonas fluorescens improves growth of the plants and also induces resistance to downy mildew. treatment results in enhancement of germination, seedling vigour, plant height, leaf area, tillering capacity, seed weight and yield. And also reduces the time of flowering. (Niranjan Raj et al., 2007)

Seed priming is widely recommended presowing seed treatment, proven for its invigourative effect. Seed priming is a technique for enhancing the seed quality and improving the overall germination and seed storage in a wide range of crop species (McDonald, 2000).

Effect of integrated nutrient approach on yield and quality of crops is reported by many workers from India and elsewhere in different millets. Fertilizer application plays an important role in vegetative growth of plants and finally increases biomass and yield.

\section{Materials and Methods}

Treatment details are given below.

\section{Treatment Details}

\section{Factor-I: Seed priming (P) Factor-II: Nutrient management (N)}

$\mathrm{P}_{1}-$ Control - No priming

$\mathrm{P}_{2}$ - Hydro priming

$\mathrm{P}_{3}$ - Seed priming with $20 \%$ Pseudomonas fluorescens

$\mathrm{P}_{4}$ - Seed priming with $2 \% \mathrm{KH}_{2} \mathrm{PO}_{4}$

\section{Results and Discussion}

All the seed quality parameters differed significantly due to seed priming treatments.

$$
\begin{aligned}
& \mathrm{N}_{1}-100 \% \mathrm{RDF} \\
& \mathrm{N}_{2}-125 \% \mathrm{RDF} \\
& \mathrm{N}_{3}-150 \% \mathrm{RDF}
\end{aligned}
$$

The prosomillet seeds primed with $\mathrm{KH}_{2} \mathrm{PO}_{4} @$ 2 per cent $\left(\mathrm{P}_{4}\right)$ recorded significantly higher seed germination per cent (86.3\%). Pseudomonas fluorescens @ 20 per cent $\left(\mathrm{P}_{3}\right)$ 
noticed highest germination percentage $(86.2$ $\%)$, seedling dry weight $(420 \mathrm{mg})$, lower electrical conductivity $\left(0.016 \mathrm{dSm}^{-1}\right)$, root length $(12.77 \mathrm{~cm})$, shoot length $(11.99 \mathrm{~cm})$, seedling length $(24.76 \mathrm{~cm})$, seedling vigour index I and II (2067 and 35342 respectively) and lower seed moisture content (8.22) (Table 1 and 2).

Table.1 Influence of seed priming treatments and nutrient management on germination (\%), root length $(\mathrm{cm})$, shoot length $(\mathrm{cm})$, seedling length $(\mathrm{cm})$ of proso millet $\mathrm{cv}$. HP-4

\begin{tabular}{|c|c|c|c|c|}
\hline Treatments & $\begin{array}{c}\text { Germination } \\
(\%)\end{array}$ & $\begin{array}{l}\text { Root length } \\
\text { (cm) }\end{array}$ & $\begin{array}{l}\text { Shoot length } \\
\text { (cm) }\end{array}$ & $\begin{array}{c}\text { Seedling length } \\
\text { (cm) }\end{array}$ \\
\hline \multicolumn{5}{|l|}{ Priming treatment } \\
\hline $\mathbf{P}_{1}$ : Control & 76.4 & 10.21 & 10.32 & 20.53 \\
\hline $\begin{array}{l}P_{2}: \text { Hydro priming } \\
\text { for } 8 \mathrm{~h}\end{array}$ & 79.6 & 10.46 & 10.56 & 20.78 \\
\hline $\begin{array}{l}\mathbf{P}_{3}: \text { Pseudomonas } \\
\text { fluroscens @20\% }\end{array}$ & 86.2 & 12.77 & 11.99 & 24.76 \\
\hline $\mathrm{P}_{4}: \mathrm{KH}_{2} \mathrm{PO}_{4} @ 2 \%$ & 86.3 & 11.20 & 11.21 & 22.41 \\
\hline Mean & 82.15 & 11.16 & 11.02 & 22.18 \\
\hline SEm \pm & 0.442 & 0.085 & 0.079 & 0.107 \\
\hline CD @ 1\% & 1.304 & 0.251 & 0.233 & 0.317 \\
\hline \multicolumn{5}{|l|}{ Nutrient management } \\
\hline $\mathrm{N}_{1}: 100 \% \mathrm{RDF}$ & 80.8 & 10.97 & 10.94 & 21.91 \\
\hline $\mathrm{N}_{2}: 125 \%$ RDF & 82.7 & 11.02 & 11.05 & 22.09 \\
\hline $\mathrm{N}_{3}: 150 \% \mathrm{RDF}$ & 83.0 & 11.49 & 11.07 & 22.54 \\
\hline Mean & 82.14 & 11.16 & 11.02 & 22.18 \\
\hline SEm \pm & 0.382 & 0.074 & 0.068 & 0.093 \\
\hline CD@ @ 1\% & 1.129 & 0.217 & 0.201 & 0.275 \\
\hline \multicolumn{5}{|c|}{$\mathbf{P} \times \mathbf{N}($ Priming $\times$ Nutrient management $)$} \\
\hline $\mathbf{P}_{1} \mathbf{N}_{1}$ & 76.3 & 9.41 & 9.82 & 19.23 \\
\hline $\mathbf{P}_{1} \mathbf{N}_{2}$ & 80.7 & 10.32 & 10.58 & 20.90 \\
\hline $\mathbf{P}_{1} \mathbf{N}_{3}$ & 81.3 & 10.76 & 10.63 & 21.39 \\
\hline $\mathbf{P}_{2} \mathbf{N}_{1}$ & 74.7 & 10.31 & 10.40 & 20.71 \\
\hline $\mathbf{P}_{2} \mathbf{N}_{2}$ & 76.3 & 10.49 & 10.48 & 20.97 \\
\hline $\mathbf{P}_{2} \mathbf{N}_{3}$ & 78.7 & 10.73 & 10.73 & 21.46 \\
\hline $\mathbf{P}_{3} \mathbf{N}_{1}$ & 82.0 & 12.35 & 10.55 & 22.90 \\
\hline $\mathbf{P}_{3} \mathbf{N}_{2}$ & 87.7 & 12.93 & 11.44 & 24.37 \\
\hline $\mathbf{P}_{3} \mathbf{N}_{3}$ & 89.2 & 13.02 & 11.63 & 24.65 \\
\hline $\mathbf{P}_{4} \mathbf{N}_{1}$ & 86.4 & 10.46 & 11.20 & 21.46 \\
\hline $\mathbf{P}_{4} \mathbf{N}_{2}$ & 86.7 & 11.37 & 11.22 & 23.59 \\
\hline $\mathbf{P}_{4} \mathbf{N}_{3}$ & 87.2 & 11.79 & 11.36 & 24.15 \\
\hline Mean & 82.14 & 11.16 & 11.02 & 22.18 \\
\hline SEm \pm & 0.765 & 0.147 & 0.137 & 0.186 \\
\hline CD @ 1\% & 2.258 & 0.434 & 0.404 & 0.549 \\
\hline
\end{tabular}


Table.2 Influence of seed priming treatments and nutrient management on seedling dry weight (mg), seedling vigour index I, seedling vigour index II and electrical conductivity of proso millet cv. HP-4

\begin{tabular}{|c|c|c|c|c|}
\hline Treatments & $\begin{array}{l}\text { Seedling dry } \\
\text { weight (mg) }\end{array}$ & $\begin{array}{c}\text { Seedling } \\
\text { vigour index I }\end{array}$ & $\begin{array}{c}\text { Seedling } \\
\text { vigour index II }\end{array}$ & $\begin{array}{c}\text { Electrical } \\
\text { conductivity } \\
\left(\mathbf{d S m}^{-1}\right)\end{array}$ \\
\hline \multicolumn{5}{|l|}{ Priming treatments } \\
\hline $\mathbf{P}_{1}$ : Control & 350 & 1588 & 26740 & 0.018 \\
\hline $\begin{array}{l}\mathbf{P}_{2} \text { : Hydro priming } \\
\text { for } 8 \mathrm{~h}\end{array}$ & 400 & 1653 & 33432 & 0.017 \\
\hline $\begin{array}{l}\mathbf{P}_{3}: \text { Pseudomonas } \\
\text { fluroscens @ 20\% }\end{array}$ & 420 & 2067 & 35342 & 0.016 \\
\hline $\mathrm{P}_{4}: \mathrm{KH}_{2} \mathrm{PO}_{4} @ 2 \%$ & 410 & 2001 & 34520 & 0.016 \\
\hline Mean & 390 & 1827 & 32509 & $\mathbf{0 . 0 1 7}$ \\
\hline SEm \pm & 0.001 & 63.42 & 81.98 & 0.0003 \\
\hline CD @ 1\% & 0.003 & 103.56 & 104.853 & 0.001 \\
\hline \multicolumn{5}{|l|}{ Nutrient management } \\
\hline $\mathrm{N}_{1}: 100 \%$ RDF & 390 & 1770 & 31512 & 0.017 \\
\hline $\mathrm{N}_{2}: 125 \%$ RDF & 400 & 1838 & 33080 & 0.017 \\
\hline $\mathrm{N}_{3}: 150 \%$ RDF & 400 & 1864 & 33280 & 0.017 \\
\hline Mean & 390 & 1824 & 32624 & 0.017 \\
\hline SEm \pm & 0.001 & 62.572 & 82.54 & 0.0002 \\
\hline CD @ 1\% & 0.005 & 98.621 & 101.584 & 0.0008 \\
\hline \multicolumn{5}{|c|}{ P $\times \mathbf{N}($ Priming $\times$ Nutrient management) } \\
\hline $\mathbf{P}_{1} \mathbf{N}_{1}$ & 320 & 1436 & 28386 & 0.018 \\
\hline $\mathbf{P}_{1} \mathbf{N}_{2}$ & 330 & 1689 & 31473 & 0.016 \\
\hline $\mathbf{P}_{1} \mathbf{N}_{3}$ & 390 & 1726 & 32046 & 0.017 \\
\hline $\mathbf{P}_{2} \mathbf{N}_{1}$ & 390 & 1595 & 31707 & 0.017 \\
\hline $\mathbf{P}_{2} \mathbf{N}_{2}$ & 490 & 1619 & 31283 & 0.017 \\
\hline $\mathbf{P}_{2} \mathbf{N}_{3}$ & 410 & 1664 & 33054 & 0.016 \\
\hline $\mathbf{P}_{3} \mathbf{N}_{1}$ & 400 & 1887 & 32960 & 0.017 \\
\hline $\mathbf{P}_{3} \mathbf{N}_{2}$ & 410 & 2138 & 35957 & 0.016 \\
\hline $\mathbf{P}_{3} \mathbf{N}_{3}$ & 430 & 2198 & 38356 & 0.015 \\
\hline $\mathbf{P}_{4} \mathbf{N}_{1}$ & 380 & 1955 & 28413 & 0.017 \\
\hline $\mathbf{P}_{4} \mathbf{N}_{2}$ & 410 & 1997 & 28446 & 0.017 \\
\hline $\mathbf{P}_{4} \mathbf{N}_{3}$ & 420 & 2067 & 34008 & 0.017 \\
\hline Mean & 390 & 1831 & 32174 & 0.0166 \\
\hline SEm \pm & 0.002 & 65.879 & 85.356 & 0.000 \\
\hline CD@ 1\% & 0.005 & 105.385 & 103.897 & 0.000 \\
\hline
\end{tabular}

While significantly minimum was recorded in control $\left(\mathrm{P}_{1}\right)\left(76.4 \%, 350 \mathrm{mg}, 0.018 \mathrm{dSm}^{-1}\right.$, $10.21 \mathrm{~cm}, 10.32 \mathrm{~cm}, 20.53 \mathrm{~cm}, 1588$ and
26740 and 13.89 respectively). All the seed quality parameters differed significantly due to nutrient management. The prosomillet 
seeds applied $150 \quad \% \quad \mathrm{RDF}$ recorded significantly higher seed germination per cent $(83.0 \%)$, seedling dry weight (400 mg), lower electrical conductivity $\left(0.017 \mathrm{dSm}^{-1}\right)$, root length $(11.49 \mathrm{~cm})$, shoot length $(11.07 \mathrm{~cm})$, seedling length $(22.54 \mathrm{~cm})$, seedling vigour index I and II (1864 and 33280 respectively) and lower moisture content (9.67). While significantly minimum was recorded in $100 \%$ $\operatorname{RDF}\left(\mathrm{N}_{1}\right)\left(80.8 \%, 350 \mathrm{mg}, 0.017 \mathrm{dSm}^{-1}\right.$, $10.97 \mathrm{~cm}, 10.94 \mathrm{~cm}, 21.91 \mathrm{~cm}, 1770,31512$ and 11.33 , respectively).

Among interaction between different seed priming treatments and nutrient management seed quality parameters differed significantly. The seeds treated with Pseudomonas fluorescens @20 per cent coupled with 150 $\%$ RDF $\left(\mathrm{P}_{3} \mathrm{~N}_{3}\right)$ recorded highest seed germination per cent $(89.2 \%)$, seedling dry weight $(430 \mathrm{mg})$, lower electrical conductivity $\left(0.015 \mathrm{dSm}^{-1}\right)$, root length (13.02 $\mathrm{cm})$, seedling length $(24.65 \mathrm{~cm})$, seedling vigour index I and II (2198 and 38356 respectively) and lower moisture content (7.67). But for shoot length is higher in $\mathrm{KH}_{2} \mathrm{PO}_{4}$ with $150 \%$ RDF $\left(\mathrm{P}_{4} \mathrm{~N}_{3}\right)$ which showed $(12.36 \mathrm{~cm})$.

While significantly minimum recorded in control along with $100 \% \operatorname{RDF}\left(\mathrm{P}_{1} \mathrm{~N}_{1}\right)(76.3$ $\%, 330 \mathrm{mg}, 0.018 \mathrm{dSm}^{-1}, 9.41 \mathrm{~cm}, 9.82 \mathrm{~cm}$, $19.23 \mathrm{~cm}, 1436$ and 28386 and 17.33 respectively).

The priming with Pseudomonas fluorescens was evident among all the treatments in improving the seed germination and seedling vigour in pearl millet by Raj et al., (2004). The enhancement in the seedling growth noticed in this study could be attributed to suppressions of deleterious microorganisms and pathogens; production of plant growth regulators such as gibberellins, cytokinins and indole acetic acid, which increased the availability of minerals and other ions and more water uptake (Ramamoorthy et al., 2000).

The increased germination percentage in primed seeds may be due to reactivation of metabolic process of seeds which cause biosynthesis of auxin, which ultimately triggers the growth of embryo (Khan, 1999) and shortening of imbibition time (Anisa et al., 2017) which leads to enhancement of internal activity during the second germination stage for any subsequent germination process (Sang In Shim et al., 2008). The $\mathrm{KH}_{2} \mathrm{PO}_{4}$ primed seeds have increased metabolic activity which leads to endosperm weakening and mobilization of storage proteins there by increasing the germination rate (De Castro et al., 2000) and during the increased metabolic activity enhanced ribonucleic acid (RNA) synthesis also leads to accumulation of 4C nuclei in the radicle meristem (Coolbear et al., 1979). The results are in accordance with the findings of Zheng et al., (1994) for canola, lettuce and onion, Nascimento (2003) and Nascimento and Aragao (2004) for muskmelon.

The increase in the seedling vigour index may be attributed to higher germination and dry matter, also priming with $\mathrm{KH}_{2} \mathrm{PO}_{4}$ was found to increase enzyme activity which leads to increased metabolic activity Srimati et al., (2013). Mirabi and Hasanabadi (2012) observed beneficial effect of $\mathrm{KH}_{2} \mathrm{PO}_{4}$ to improve seedling vigour index in tomato. These results are in accordance with Kavitha, 2007 in chilli and Ghassemi et al., (2010) in lentil.

Release of certain enzymes responsible for degradation of macromolecules into micro molecules within the seed are not influenced by different combinations of integrated nutrient management as applied to the soil. The similar results were reported by Kumar and Uppar (2007) in moth bean and Chawale et al., (1995) in groundnut. The metabolites 
release certain enzymes responsible for degradation of macromolecules into micro molecules within the seed responsible for the higher growth of seedling increased the dry weight. Similar results were reported by Kumar and Uppar (2007) in moth bean.

The increase in root and shoot length with primed seeds might be due to the fact that, priming induced nuclear replication in root tips of seeds (Stofella et al., 1992). The higher seedling length in seeds primed with might be attributed to enlarged embryos, higher rate of metabolic activities and respiration, better utilization and mobilization of metabolites to growing points and higher activity of enzymes. The results corroborate with the findings of Hussaini et al., (1988) in tomato, Ramamoorthy et al., (1989) in coriander and Shahazad (2003) in wheat.

Significantly lowest electrical conductivity by priming might be due to enhanced repair of membrane, which is disrupted during maturation drying. Since electrolyte leakage is in part a result of damage cell membranes. However, electrolytes may leak out during priming, resulting in lower levels of electrolytes in non-primed seeds (Chiu et al., 1995). In the present, study the differential EC values which were recorded among the seed priming treatments indicate the nature and extent of membrane protection offered, which may not be the same for all seed priming treatments, thus resulting in difference in EC values as stated by Kurdikeri (1993) and Sandyarani (2002) in cotton. Similar results were also reported in soybean (Sung and Chiu, 1995), carrot (Maskari et al., 2003) and turnip (Khan et al., 2005).

The accumulation of higher quantities of seed constituents like carbohydrates, protein and other enzymes due to different nutrient combinations. Increase in seedling length may be because of bolder seeds, having higher test weight which contains greater metabolites for resumption of embryonic growth during germination and these metabolites release certain enzymes responsible for degradation of macromolecules into micro molecules within the seed for the increase of seedling length. The results were reported by Kumar and Uppar (2007) in moth bean.

The application of inorganic fertilizers along with bio-fertilizers inoculation enhances the accumulation of higher quantities of seed constituents like carbohydrates, proteins as enzymes which increased the seedling vigour index of bolder seeds that contain greater metabolites for resumption of embryonic growth during germination. In addition to these metabolites release of certain enzymes responsible for degradation of macromolecules into micro molecules within the seed as stated by Kumar and Uppar (2007) in moth bean.

In conclusion, the prosomillet seeds primed with Pseudomonas fluorescens 20 per cent for $8 \mathrm{~h}$ along with $150 \%$ RDF showed higher seed quality parameters viz., germination, shoot and root length, vigour index and lower electrical conductivity.

\section{References}

Anisa, R., Wanchai, C., Pitipong, T., and Damrongvudhi, O., 2017. Effect of seed priming with different concentration of potassium nitrate on the pattern of seed imbibition and germination of rice (Oryza sativa L.). Journal of Integrative Agriculture. 16(3): 605-613.

Bradford, K. J., 1986. Manipulation of seeds water relations via osmotic priming to improve germination under stress conditions. Hort. Sci., 59(2): 672-676.

Chawale, V. V., Bharade, G. M., Kohale, S. K., and Nagadeve, M. B., 1995. Effect of nitrogen and FYM on yield, quality 
and nitrogen uptake of summer groundnut under micro sprinkler irrigation, Punjabrao Krishi Vishwa Vidhyalaya. Res. J. 19(2): 171-172.

Chiu, K. Y., and Sung, J. M., 2002. effect of priming temperature on storability of primed sweet corn seed. Crop Sci., 42:1996-2003.

Coolbear, P., Grierson, D., and Heydecker, W., 1979. Osmotic presowing treatments and nucleic acid accumulation in tomato seed (Lycopersicon esculentus Mill.). Seed Sci. Technol., 8: 289-303.

Gavit, H. D., Rajemahadik, V. A., Bahure, G. K., Jadhav, M. S., Thorat, T. N., and Kasture, M. C., 2017. Effect of establishment techniques and sowing time on yield and yield attributes of proso Millet (Panicum miliaceum L.), Int. J. Curr. Microbiol. App. Sci., 6(5): 1523-1528.

Hassan, S. M. E., Rahman, M. S., Hossain, M. F., Amin, M. R., and Alam, M. M., 2000. Evaluation of planting density and nitrogen on the performance of Kaon (Setaria italica (L). Beauv.), Pakistan Bio. Sci.,. 3(11), 1863-1864.

Ghassemi-Golezani, K., Aliloo, A. A., Valizadeh, M., and Moghaddam, M., 2010. Effects of different priming techniques on seed invigoration and seedling establishment of lentil (Lens culinaris M.). J. Food Agric. Environ., 6: 222-226.

Hussaini, S. H., Ahmed, Z. A., and Dhanrai, A., 1988. The effect of accelerated ageing on germination, vigour and yield of maize. Seed Res., 16: 68-75.

Kavitha, M., 2007. Seed quality enhancement and storability studies in chilli (Capsicum annum L.) M.Sc. (Agri.) Thesis, Univ. Agric. Sci., Dharwad (India).

Khan, A., Khalil, S. K., Khan, S., and Afzal, A., 2005. Priming effects on crop stand of turnip. Sarhad J. Agric., 21: 535-538

Kumar, A. S. H., and Uppar, D. S., 2007. Influence of Integrated Nutrient Management on Seed Yield and Quality of Mothbean (Vigna aconitifolia Jacq. Marchel), Karnataka J. Agric. Sci., 20(2): 394-396.

Kurdikeri, M. B., Ashwataiah, B., and Rajendra Prasad, S., 1993. Seed quality of invigourated seeds of maize hybrid. Mysore J. Agril. Sci., 27:237-242.

Maskari, A. I., Khan, A. Y., Khan, I. A., and Habsi, K., 2003. Effect of accelerated ageing on viability, vigour (RGR), lipid peroxidation and leakage in carrot (Daucus carota L.) seeds. Inter. J. Agric. Biol. 5(4): 580-584.

Mirabi, E., and Hasanbadi, M., 2012. Effect of seed priming on some characteristic of seedling and seed vigor of tomato. $J$. Advan. Laboratory Res. in Biol., 3(3): 278-282.

Mohammadi, G. R., Dezfuli, M. P. M., and Sharifzadeh, F., 2008. Seed invigoration techniques to improve germination and early growth of inbred line of maize under salinity and drought stress. Gen. Appl. Plant Physiol. 34:215-226.

Nascimento, W. M., and Souza de Aragao, F. A., 2004. Muskmelon seed priming in relation to seed vigor. Sci. Agric., 61: 114-117

Nascimento, W. M., 2003. Muskmelon seed germination and seedling development in response to seed priming. Scientia Agricola, 60: 71-75.

Niranjan, R. S., Shetty, N. P., and Shetty, H. S., 2004. Seed bio-priming with Pseudomonas fluorescens isolates enhances growth of pearl millet plants and induces resistance against downy mildew, International J. pest manage., 50(1): 41-48.

Patil, S. V., Bhosale, A. S., and Khambal, P. D, 2015. effect of various levels of fertilizers on growth and yield of finger 
millet. J. Agric. Veterinary Sci., 8, (6):49-52.

Ramamoorthy, K., Natarajan, N., and Lakshmanan, A., 2000. Seed biofortification with Azospirillum spp. for improvement of seedling vigour and productivity in rice (Oryza sativa L.). Seed Sci. \& Technol., 28(3): 809-815.

Sandyarani, G. M., 2002. Influence of seed treatment with chemicals and botanical on storability and field performance of fresh and aged hybrid cotton seeds. M.Sc. (Agri.) Thesis. University of Agricultural Sciences, Dharwad.

Shahazad, H. M., Ahmad, B., Imtiaz, A. P., and Irfaan, A., 2003. Pre-sowing seed treatments to improve germination and seedling growth in wheat (Triticum aestivum). M.Sc. (Agri.) Thesis. Department of Crop Physiology, University of Agriculture, Faisalabad38040, Pakistan.

Srimathi, P., Mariappan, N.,
Sundaramoorthy, L., and Paramathma, M., 2013. Efficacy of panchagavya on seed invigoration of biofuel crops. Scientific Res. Essays, 8(41): 20312037.

Stofella, P. J., Lipucci, D. P., Pardossi, A., and Tognoni, F., 1992. Seedling root morphology and shoot growth after seed priming or pregermination of bell pepper. Hortic. sci., 27: 214-215.

Subedi, D. K., and Ma, B. L., 2005. Seed priming does not improve corn yield in a humid temperate environment. Agron. J., 97: 211-218.

Sung, J. M., and Chiu, C. C., 1995. Lipid peroxidation and peroxide scavenging enzymes of naturally aged edible soybean seeds. Pl. Sci., 110: 45-52.

Zheng, M. Y. W. H. S., 2012. Osmo priming improves tomato seed vigour under ageing and salinity stress. African Journal of Biotechnology, 11: 63056311.

\section{How to cite this article:}

Tejaswini, U., S.M. Prashant, N.M. Shakuntala, Sangeetha I. Macha and Krishnamurthy, D. 2019. Investigation on Maximization of Seed Quality and through Integrated Approach in Prosomillet (Panicum miliaceum L.). Int.J.Curr.Microbiol.App.Sci. 8(09): 161-168. doi: https://doi.org/10.20546/ijcmas.2019.809.021 